\title{
The Influences of Energy Price Variation on the Prices of Other Industries: A Study Based on Input-Output Price Model
}

\author{
Aiwen Zhao' ${ }^{1}$, Ruilin $\mathrm{Li}^{2}$ \\ ${ }^{1}$ School of Economics, Xuzhou Institute of Technology, Xuzhou, China \\ ${ }^{2}$ Jincheng School, Nanjing University of Aeronautics and Astronautics, Nanjing, China \\ Email:xzzhaoaiwen@163.com
}

How to cite this paper: Zhao, A.W. and Li, R.L. (2019) The Influences of Energy Price Variation on the Prices of Other Industries: A Study Based on Input-Output Price Model. Open Journal of Energy Efficiency, 8, 35-51. https://doi.org/10.4236/ojee.2019.82003

Received: March 22, 2019

Accepted: June 1, 2019

Published: June 4, 2019

Copyright $\odot 2019$ by author(s) and Scientific Research Publishing Inc. This work is licensed under the Creative Commons Attribution International License (CC BY 4.0).

http://creativecommons.org/licenses/by/4.0/

\begin{abstract}
Energy has laid material foundation for human society during its development. Meanwhile, any change of price in the energy industry may influence social production and people's life at all levels via an input-output mechanism under which the change related to energy is surely transmitted to other industries. The price change thus incurred in all industries may adversely affect the realization of macroeconomic objective-maintaining prices at a stable level. It is, therefore, needed to conduct an empirical research related to the impact of price change in energy industry on that in other industries. According to the data coming from "China's 2015 Input-Output Extension Table (42 Departments)" and four hypothetical basis, this article focuses on four energy sectors and analyzes how deeply the price change of them, by use of input-output model, affects that of other industrial products under five conditions where each of their price rises by $10 \%$ individually or simultaneously, and why such an influence occurs. The results show that the price rising of the energies in question leads to an upward growth in the prices of other industrial products, especially when their prices go up simultaneously. Besides, the price increase in the four energy sectors doesn't influence other industries in an accumulation form but actually leads to a rollback in some of other industries. It is recommended to adopt diversified pricing strategies for different energy products, thus maximizing the value of each specific energy, and meanwhile achieving the goals of energy consumption reduction and price equilibrium.
\end{abstract}

\section{Keywords}

Energy Price Variation, Input-Output, Price Model 


\section{Introduction}

Since energy is understood to have laid foundation materially for human society, any pricing change in the energy industry may, on the one hand, influence social production and people's life at all levels, and on the other hand is closely connected with industrial development via an input-output mechanism. All in all, the price change in energy industry may bring about that in other industries, and ultimately influence the realization of macroeconomic objective of maintaining prices at a stable level. Changes in energy prices are both directly reflected in the consumer price index (CPI) through the channels of means of subsistence, and indirectly on the producer price index (PPI) with the rise in raw materials and manufacturing elements [1]. As China's energy price mechanism has not yet fully marketed, it is especially complex for this study.

That is, in terms of energy prices, some of energy-resource products cannot fully reflect their value, which not only causes waste of resources, but also adversely affects adjustment of national economy. In 2015, China's government proposed the promotion of energy production and consumption revolution, and also that the energy price is to be decided by the market. To sum up, the contradiction existing in the energy industry in terms of supply and demand, together with severe environmental pollution, is attributed to energy price.

Based on data from "China's 2015 Input-Output Extension Table (42 Departments)" and four hypothetical conditions, this article highlights four energy sectors and analyzes how deeply the price change of them, by use of input-output model, affects that of other industrial products under five conditions where each of their price rises by $10 \%$ individually or simultaneously, and why such an influence occurs. In this sense, this study may empower energy industry and other industries as well either in theory or in practice.

\section{Literature Review}

The issues concerning energy pricing have been discussed widely by many scholars from abroad. Hotelling (1931) [2] proposed so-called Hotelling, an exhaust resource model, and thus pioneered the study of oil-price fluctuation mechanism. The amount of study focusing on oil pricing has risen increasingly after two worldwide oil crisis. American scholars Arrow and Chang (1982) [3], starting from the uncertainty of resource stocks, fully analyzed the situation where oil price changes not in conformity with Hotelling model using the mathematical method concerning optimal control of uncertainty. Hamilton (1983) [4], Burbidge, and Harrison (1984) [5] explained the impact of oil price changes on the economic cycle using the vector auto-regressive method. However, Adelman (1993) [6] didn't accept the model of exhaustible resources but proposed that oil prices are not determined by the Hotelling model. In spite of all the conflicting opinions, the Hotelling model has been practically applied as one of analytical standards. Lee and $\mathrm{Ni}$ (2002) [7] pointed out that almost no correlation existed between the decline in output caused by rising oil prices and the oil intensity of 
various industries when analyzing the impact of crude oil price shocks on the supply and demand of various industries in the US manufacturing industry. Jiménez-Rodríguez (2005) [8] studied the dynamic impact of crude oil price shocks on manufacturing industries in six OECD countries, providing evidence for whether oil shock effects vary in different industries.

The research conducted by China's scholars didn't boom until the earlier $21^{\text {st }}$ century. Their research, mainly based on CGE and input-output models, is mainly focused on energy price formation mechanisms and the relationship between energy prices and economic growth rather than between energy prices and other industry prices. Typically, Zeping (2007) [9] explored the impact of crude oil prices on China's total price level based on the input-output method. Furthermore, Boqing Lin (2008) [10] and other scholars identified that the increase in energy price may lead to tightness of industries at different levels, and further to the changes of their structure using the CGE model. They (2009) [1] deepened their study later by using the input-output price impact model on the assumption that the energy prices were under control or out of control. As shown in the simulation conducted to test whether the rise in energy prices would lead to the same trend of general prices, price controlling would result in conduction of energy prices to a general extent. Zeping Ren (2012) [11] studied the influence of energy price fluctuation on the price system and the diversity thus occurred based on an improved input-output price model. The results demonstrated the facts that the impact on the upstream price is greater than on the downstream price, that the impact on the production fields is greater than on the consumer sectors, and that the impact on the enterprises is greater than on the residents' consumption. Wei Wang and other scholars (2012) [12], using the input-output model, figure out the impact caused by fluctuation of coal prices on various sectors and/or industries, and further measured the direct consumption coefficient and complete consumption coefficient in terms of coal consumed by all sectors involved in national economy. The analysis results show that any change in coal price will influence the production and supply sectors of electricity and heat most greatly. For example, if the coal price rises by $10 \%$, the price of any product coming from these sectors will increase by $1.79 \%$. Jun Yang and other scholars (2012) [13] constructed an input-output price model that was then used to explain the impact of coal price changes on other industries. As shown, it is the heavy chemical sectors included in China's secondary industry that has been greatly influenced by the change of coal prices with a high-level sensitivity, different from China's primary and tertiary industries that are influenced weakly. Xin Zhang and other scholars (2013) [14], referring to the input-output price model, measured the impact the increase in China's fossil energy price on prices of products manufactured by other industrial sectors. Huaming Zhang and other scholars (2013) [15] conducted an empirical analysis of the influence mechanism of four energy industries on their related industries in prices based on four assumption using the input-output price model, and then 
discussed the quantitative relationship of price-conducting chains. The research shows that the influence level varies with energy, even forming a spiral between some sectors. Xiaohua Xu (2014) [16] explored the input-output relationship between the coal industry and every sector of the national economy, followed by the conclusion that an increase in coal price will surely influence the prices of other products without exception, which indicates that changes in coal prices not only affected coal-related industries but all walks of national economy. Yongda He (2017) [17] simulated the impact of price volatility of international natural gas on residents' living and industrial structure under different scenarios after having designing an imperfect-competition CGE model.

Although both the CGE model and the input-output model are similarly effective when used to analyze price problems, the former, compared with the latter, is related with higher requirements for data, more complicated modeling construction, and higher cost incurred. The input-output model, however, is in a good position to avoid errors that occur in CGE model when balancing the social accounting matrix and calibration parameters, though it takes no account of nonlinear relationship between economic variables and some equilibrium problems of the market. In addition, there exists an extremely complicated relationship between various sectors because the products are consumed or provided each other during a manufacturing process. When the price of a certain product changes, it will inevitably affect the cost of products in other sectors, thus affecting the prices of these products. Owing to complexity of this chain relationship, the input-output model is currently utilized as a better way to work out the interaction between them [18].

\section{Theoretical Model}

Owing to the complexity of pricing issues, it is needed to establish a reasonable price system by fully exerting the economic leverage of prices, addressing the problems occurred in calculation in ration to prices' formation and their mutual influence. The input-output price model [19] [20] [21] is, therefore, the only effective tool that could be used to determine the impact of a reasonable price system on price adjustment.

\subsection{Price Formula}

Given a uniform production tax net and operating surplus ratio for each type of commodity, the price for each can be worked out by using the input-output model. Since the columns listed in the input-output table reflect the value formation of the products in each department, that is, the formation and composition of the product prices in practice, the price formulal [19] [20] [21] is thus expressed as follows.

Price formula:

$$
P_{j}=\sum_{i=1}^{n} a_{i j} p_{i}+a_{v j}+a_{m j} \quad(j=1,2, \cdots, n)
$$


which is represented by a matrix shown below.

$$
\begin{gathered}
P=A^{\mathrm{T}} P+\bar{V}+\bar{M} \\
P=\left(I-A^{\mathrm{T}}\right)^{-1}(\bar{V}+\bar{M})
\end{gathered}
$$

In the formula, $A$ denotes direct the consumption coefficient matrix for each department, $\bar{V}$ the column vector of labor consumption coefficient for each department, $\bar{M}$ the column vector of net production tax and operating surplus ratio for each department, and $P$ the equilibrium price column vector when the supply of and demand for the products are equal.

\subsection{The Impact of Product Price Change in One Sector on That in Other Sectors}

In the process of being manufactured, products are mutually consumed or supplied to each other, resulting in a complex chain-like relationship in which the price of the products in one sector might influence that in other sectors when it goes up or down. So far, the input-output model has been used as an ideal method in price calculation.

The mutual influence caused by price change is measured by using the input-output model based on the following assumptions.

1) The price change of the affected products is caused by the change in cost of materials, regardless of the impact of changes in labor compensation and net production tax.

2) The measures that enterprises will take to reduce consumption if the price of materials and energy rises are not included.

3) The price change in supply and demand is not considered.

4) The change in depreciation of fixed assets is not considered.

Note that the above assumptions keep the generality. Assume the price of products in Sector $n$ varies with a range of $\Delta p_{n}$, then the price of products in Sector $j(j=1,2, \cdots, n)$ will change accordingly as follows.

$$
\Delta p_{j}=\sum_{i=1}^{n} a_{i j} \Delta p_{i} \quad(j=1,2, \cdots, n)
$$

or

$$
\Delta p_{j}-\sum_{i=1}^{n} a_{i j} \Delta p_{i}=0 \quad(j=1,2, \cdots, n)
$$

where $\Delta P_{i}$ and $\Delta P_{j}$ denotes the price variation index of Sector $i$ and Sector $j$, respectively. Besides, $a_{i j}$ represents the direct consumption factor in an input-output table. Equation (5) is expanded as

$$
\begin{aligned}
& \Delta P_{1}=a_{11} \Delta P_{1}+a_{21} \Delta P_{2}+\cdots+a_{n-1,1} \Delta P_{n-1}+a_{n, 1} \Delta P_{n} \\
& \Delta P_{2}=a_{12} \Delta P_{1}+a_{22} \Delta P_{2}+\cdots+a_{n-1,2} \Delta P_{n-1}+a_{n, 2} \Delta P_{n} \\
& \Delta P_{n-1}=a_{1, n-1} \Delta P_{1}+a_{2, n-1} \Delta P_{2}+\cdots+a_{n-1, n-1} \Delta P_{n-1}+a_{n, n-1} \Delta P_{n}
\end{aligned}
$$

After transposing terms, we learn 


$$
\begin{aligned}
& \Delta P_{1}=a_{11} \Delta P_{1}+a_{21} \Delta P_{2}+\cdots+a_{n-1,1} \Delta P_{n-1}+a_{n, 1} \Delta P_{n} \\
& \Delta P_{2}=a_{12} \Delta P_{1}+a_{22} \Delta P_{2}+\cdots+a_{n-1,2} \Delta P_{n-1}+a_{n, 2} \Delta P_{n} \\
& \Delta P_{n-1}=a_{1, n-1} \Delta P_{1}+a_{2, n-1} \Delta P_{2}+\cdots+a_{n-1, n-1} \Delta P_{n-1}+a_{n, n-1} \Delta P_{n}
\end{aligned}
$$

Equation (5) is expressed by a matrix as

$$
\Delta P-A^{\mathrm{T}} \Delta P=0
$$

namely,

$$
\Delta\left(I-A^{\mathrm{T}}\right) \Delta P=0
$$

Equation (7) is expressed by a matrix as

$$
\left[\begin{array}{c}
a_{n 1} \\
a_{n 2} \\
\vdots \\
a_{n, n-1}
\end{array}\right] \Delta P_{n}=\left(I_{n-1}-A_{n-1}^{\mathrm{T}}\right)\left[\begin{array}{c}
\Delta P_{1} \\
\Delta P_{2} \\
\vdots \\
\Delta P_{n-1}
\end{array}\right]
$$

According to Equation (7), a formula is obtained as follows to explain how much the price will increase from Sector 1 to Sector $(n-1)$ when the the price in Sector $n$ rises by $\Delta P_{n}$.

$$
\left[\begin{array}{c}
\Delta p_{1} \\
\Delta p_{2} \\
\vdots \\
\Delta p_{n-1}
\end{array}\right]=\left[\left(I_{n-1}-A_{n-1}\right)^{-1}\right]^{\mathrm{T}}\left[\begin{array}{c}
a_{n 1} \\
a_{n 2} \\
\vdots \\
a_{n, n-1}
\end{array}\right] \Delta p_{n}
$$

In Equation (9), $A_{n-1}^{\mathrm{T}}$ denotes the original $n$-order direct consumption coefficient matrix in the input-output table. After Row $n$ and Column $n$ being removed away, the remains represent the $(n-1)$-order transpose matrix of direct consumption coefficient. And in Equation (10),

$$
\left[\begin{array}{c}
a_{n 1} \\
a_{n 2} \\
\vdots \\
a_{n, n-1}
\end{array}\right] \Delta p_{n} \text { denotes the situation how a price increase of } \Delta P_{n} \text { in Sector } n
$$

directly affects that in Sector 1 to $(n-1)$ separately through calculation of direct consumption coefficient. Being multiplied by $\left[\left(I_{n-1}-A_{n-1}\right)^{-1}\right]^{\mathrm{T}}$, its direct and indirect effects on prices in other sectors are obtained accordingly.

\subsection{The Impact of Product Price Change in Two or More Sectors on that in Other Sectors}

1) The formula for calculating the impact of price adjustment in two sectors It can be derived from Formula (5) as follows.

$$
\left[\begin{array}{c}
a_{n-1,1} \\
a_{n-1,2} \\
\vdots \\
a_{n-1, n-2}
\end{array}\right] \Delta P_{n-1}+\left[\begin{array}{c}
a_{n 1} \\
a_{n 2} \\
\vdots \\
a_{n, n-2}
\end{array}\right] \Delta P_{n}=\left(I_{n-2}-A_{n-2}^{\mathrm{T}}\right)\left[\begin{array}{c}
\Delta P_{1} \\
\Delta P_{2} \\
\vdots \\
\Delta P_{n-2}
\end{array}\right]
$$

After the items being moved, it becomes 


$$
\left[\begin{array}{c}
\Delta p_{1} \\
\Delta p_{2} \\
\vdots \\
\Delta p_{n-2}
\end{array}\right]=\left[\left(I_{n-2}-A_{n-2}\right)^{-1}\right]^{\mathrm{T}}\left[\begin{array}{cc}
a_{n-1,1} & a_{n 1} \\
a_{n-1,2} & a_{n 2} \\
\vdots & \vdots \\
a_{n-1, n-2} & a_{n, n-2}
\end{array}\right]\left[\begin{array}{c}
\Delta p_{n-1} \\
\Delta p_{n}
\end{array}\right]
$$

2) The formula for measuring the impact of price adjustment in $k$ sectors The formula can be obtained in the same way as follows.

$$
\left[\begin{array}{c}
\Delta p_{1} \\
\Delta p_{2} \\
\vdots \\
\Delta p_{n-k}
\end{array}\right]=\left[\left(I_{n-k}-A_{n-k}\right)^{-1}\right]^{\mathrm{T}}\left[\begin{array}{ccc}
a_{n-k+1,1} & \cdots & a_{n 1} \\
\vdots & \ddots & \vdots \\
a_{n-k+1, n-k} & \cdots & a_{n, n-k}
\end{array}\right]\left[\begin{array}{c}
\Delta p_{n-k+1} \\
\Delta p_{n-k+2} \\
\vdots \\
\Delta p_{n}
\end{array}\right]
$$

\section{Data Source}

The authors employed the data from "China's 2015 Input-Output Extension Table (42 Departments)", and in accordance with standardized names in the input-output table selected four energy sectors of China's coal mining products (No. 02), oil and natural gas mining products (No. 03), petroleum, coking products and nuclear fuel processed products (No. 11), and electricity, hot gas, gas production and supply (No. 25-26). In this study, the MATLAB software was used to explain how deeply the price variation influence other industries under five conditions where each price of the four sectors rises by $10 \%$ individually and jointly at the same time.

\section{Empirical Research}

When using the input-output price model, it is necessary to obtain the direct consumption coefficient, the complete consumption coefficient, and the Leontief inverse matrix of the input-output table [19] [20] [21], which are calculated as follows.

\subsection{The Direct Consumption Coefficient}

The direct consumption coefficient (also known as the input coefficient), denoted by $a_{i j}(i, j=1,2, \cdots, n)$, referring to the value of the goods or services provided by Sector $i$ but directly consumed by the total output per unit in Sector $j$ during the process of production and operation. The direct consumption coefficient of each product (or industry) department is expressed in the form of either a direct consumption coefficient table or a direct consumption coefficient matrix, often denoted by $A$.

The direct consumption coefficient is obtained when $X_{j}$, the total input of product/sector department $j$, divides $x_{i j}$, the value of the goods or services offered by Sector $i$ and directly consumed by the department in question, with the formula shown below.

$$
a_{i j}=\frac{x_{i j}}{X_{j}} \quad(i, j=1,2, \cdots, n)
$$




\subsection{The Complete Consumption Coefficient}

The complete consumption coefficient, often denoted by $b_{i j}(i, j=1,2, \cdots, n)$, refers to the sum of direct consumption and indirect consumption of the goods and services supplied by Sector $i$ when one unit of final use comes from Sector $j$. The complete consumption coefficient matrix $B$ can be calculated based on the direct consumption coefficient matrix $A$, shown as $B=(I-A)^{-1}-I$.

\subsection{Leontief Inverse Matrix}

In the complete consumption coefficient matrix $B=(I-A)^{-1}-I$, the matrix $(I-A)^{-1}$ is called Leontief inverse matrix, represented by $\bar{B}$, in which the item $\overline{b_{i j}}(i, j=1,2, \cdots, n)$ is called Leontief inverse matrix coefficient, indicating the total demand for Sector $i$ when each unit of final use is added in Sector $j$.

\subsection{The Empirical Research}

The price changes of fossil energy are then measured by MATLAB software and the input-output price model following the analysis of direct consumption coefficient, complete consumption coefficient, and Leontief inverse matrix. The impact of an $10 \%$ price increase in Coal mining products (No. 02) on the prices of other industries are shown in Table 1.

Seen from Table 1, when the price of coal mining products (No. 02) increases, the prices of other sectors will then go up after being transmitted and influenced, which causes so-called cost-driven price rise. Among all sectors involved in Chinese national economy, a $10 \%$ price increase in the coal mining products influences the prices of other industries at different levels. Among them, the one that is influenced most greatly is the production and supply of electricity, heat and gas $(2.06 \%)$, followed by the petroleum, coking products and nuclear fuel processed products $(0.92 \%)$, the metal smelting and calendering products $(0.87 \%)$, the non-metallic mineral products $(0.73 \%)$, the chemical products $(0.59 \%)$, and the real estate products $(0.05 \%)$, with a mean of $0.36 \%$.

In addition, it is derived that if the price of coal mining products (No. 02) rises by $20 \%$ and $30 \%$ separately, the price of other products will go up 2 to 3 times greater than that when it rises by $10 \%$, and so on.

The impact of a $10 \%$ price increase in oil and gas extraction products (No. 03) on the prices of other sectors are shown in Table 2.

It can be learned from Table 2 that if the price of the oil and gas extraction products (No. 03) increases, the prices of other sectors will then go up after being transmitted and influenced owing to the input and output relations between manufacturing sectors, which results in so-called cost-driven price rise. Among all sectors involved in Chinese national economy, a $10 \%$ increase in product prices of the oil and gas extraction products influences those of other sectors differently, of which the one that is affected most greatly comes from the petroleum, coking products and nuclear fuel processed products (4.46\%), followed in sequence by the production and supply of electricity, heat and gas $(0.84 \%)$, the 
Table 1. The impact of an increase of $10 \%$ in prices of the coal mining products (No. 02) on other industrial products.

\begin{tabular}{|c|c|c|c|c|c|c|c|}
\hline Ranking & Sector & No. & $\begin{array}{l}\text { Variation } \\
\text { Range }\end{array}$ & Ranking & Sector & No. & $\begin{array}{l}\text { Variation } \\
\text { Range }\end{array}$ \\
\hline 1 & $\begin{array}{l}\text { Production and supply of } \\
\text { electricity, heat and gas }\end{array}$ & $25-26$ & $2.06 \%$ & 22 & $\begin{array}{l}\text { Communication equipment, } \\
\text { computers and other } \\
\text { electronic equipment }\end{array}$ & 20 & $0.26 \%$ \\
\hline 2 & $\begin{array}{l}\text { Petroleum, coking products } \\
\text { and nuclear fuel processed } \\
\text { products }\end{array}$ & 11 & $0.92 \%$ & 23 & $\begin{array}{l}\text { Wood processed products } \\
\text { and furniture }\end{array}$ & 9 & $0.26 \%$ \\
\hline 3 & $\begin{array}{l}\text { Metal smelting and } \\
\text { calendering products }\end{array}$ & 14 & $0.87 \%$ & 24 & $\begin{array}{l}\text { Transportation, warehousing } \\
\text { and postal services }\end{array}$ & 30 & $0.25 \%$ \\
\hline 4 & $\begin{array}{l}\text { Non-metallic mineral } \\
\text { products }\end{array}$ & 13 & $0.73 \%$ & 25 & Textile & 7 & $0.23 \%$ \\
\hline 5 & Chemical products & 12 & $0.59 \%$ & 26 & Leasing and business services & 35 & $0.20 \%$ \\
\hline 6 & Metal products & 15 & $0.56 \%$ & 27 & $\begin{array}{l}\text { Water, environmental and } \\
\text { public facilities management }\end{array}$ & 37 & $0.20 \%$ \\
\hline 7 & Metal mining products & 4 & $0.48 \%$ & 28 & $\begin{array}{l}\text { Scientific research and } \\
\text { technical services }\end{array}$ & 36 & $0.19 \%$ \\
\hline 8 & Wasted products or materials & 23 & $0.48 \%$ & 29 & $\begin{array}{l}\text { Textile clothing, shoes and } \\
\text { hats, leather down and its } \\
\text { products }\end{array}$ & 8 & $0.18 \%$ \\
\hline 9 & $\begin{array}{l}\text { Production and supply } \\
\text { of water }\end{array}$ & 27 & $0.46 \%$ & 30 & $\begin{array}{l}\text { Resident services, repairs } \\
\text { and other services }\end{array}$ & 38 & $0.15 \%$ \\
\hline 10 & $\begin{array}{l}\text { Other manufactured } \\
\text { products }\end{array}$ & 22 & $0.46 \%$ & 31 & Food and tobacco & 6 & $0.13 \%$ \\
\hline 11 & $\begin{array}{l}\text { Electrical machinery and } \\
\text { equipment }\end{array}$ & 19 & $0.45 \%$ & 32 & $\begin{array}{l}\text { Information transfer, } \\
\text { software and information } \\
\text { technology services }\end{array}$ & 32 & $0.12 \%$ \\
\hline 12 & Buildings & 28 & $0.42 \%$ & 33 & $\begin{array}{l}\text { Agriculture, forestry, animal } \\
\text { husbandry and fishery } \\
\text { products and services }\end{array}$ & 1 & $0.12 \%$ \\
\hline 13 & $\begin{array}{l}\text { Non-metallic minerals and } \\
\text { other mining products }\end{array}$ & 5 & $0.42 \%$ & 34 & $\begin{array}{l}\text { Culture, sports and } \\
\text { entertainment }\end{array}$ & 41 & $0.11 \%$ \\
\hline 14 & General equipment & 16 & $0.39 \%$ & 35 & Accommodation and dining & 31 & $0.10 \%$ \\
\hline 15 & $\begin{array}{l}\text { Paper printing \& cultural, } \\
\text { educational, and sporting } \\
\text { goods }\end{array}$ & 10 & $0.37 \%$ & 36 & $\begin{array}{l}\text { Public administration, } \\
\text { social security and social } \\
\text { organization }\end{array}$ & 42 & $0.10 \%$ \\
\hline 16 & Professional equipment & 17 & $0.36 \%$ & 37 & Wholesale and Retail & 29 & $0.08 \%$ \\
\hline 17 & $\begin{array}{l}\text { Repair of metal products, } \\
\text { machinery and equipment }\end{array}$ & 24 & $0.34 \%$ & 38 & Finance & 33 & $0.06 \%$ \\
\hline 18 & $\begin{array}{l}\text { Oil and gas extraction } \\
\text { products }\end{array}$ & 3 & $0.33 \%$ & 39 & Education & 39 & $0.06 \%$ \\
\hline 19 & Transportation equipment & 18 & $0.31 \%$ & 40 & Real estate & 34 & $0.05 \%$ \\
\hline 20 & Instruments & 21 & $0.27 \%$ & & \multirow{2}{*}{ Mean } & & \multirow{2}{*}{$0.36 \%$} \\
\hline 21 & Health \& social work & 40 & $0.27 \%$ & & & & \\
\hline
\end{tabular}

Data source: arranged and measured in accordance with China's 2015 input-output extension table (42 departments). 
Table 2. The impact of an increase of $10 \%$ in prices of the oil and gas extraction products (No. 03) on other industrial products.

\begin{tabular}{|c|c|c|c|c|c|c|c|}
\hline Ranking & Sector & No. & $\begin{array}{l}\text { Variation } \\
\text { Range }\end{array}$ & Ranking & Sector & No. & $\begin{array}{l}\text { Variation } \\
\text { Range }\end{array}$ \\
\hline 1 & $\begin{array}{l}\text { Petroleum, coking products and } \\
\text { nuclear fuel processed products }\end{array}$ & 11 & $4.46 \%$ & 22 & $\begin{array}{l}\text { Scientific research and } \\
\text { technical services }\end{array}$ & 36 & $0.28 \%$ \\
\hline 2 & $\begin{array}{l}\text { Production and supply of } \\
\text { electricity, heat and gas }\end{array}$ & $25-26$ & $0.84 \%$ & 23 & Coal mining products & 2 & $0.26 \%$ \\
\hline 3 & Chemical products & 12 & $0.66 \%$ & 24 & $\begin{array}{l}\text { Wood processed products } \\
\text { and furniture }\end{array}$ & 9 & $0.25 \%$ \\
\hline 4 & $\begin{array}{l}\text { Metal smelting and } \\
\text { calendering products }\end{array}$ & 14 & $0.62 \%$ & 25 & $\begin{array}{l}\text { Communication equipment, } \\
\text { computers and other } \\
\text { electronic equipment }\end{array}$ & 20 & $0.25 \%$ \\
\hline 5 & $\begin{array}{l}\text { Transportation, warehousing } \\
\text { and postal services }\end{array}$ & 30 & $0.60 \%$ & 26 & Instruments & 21 & $0.25 \%$ \\
\hline 6 & Metal mining products & 4 & $0.46 \%$ & 27 & Textile & 7 & $0.22 \%$ \\
\hline 7 & $\begin{array}{l}\text { Non-metallic minerals and } \\
\text { other mining products }\end{array}$ & 5 & $0.46 \%$ & 28 & $\begin{array}{l}\text { Water, environmental and } \\
\text { public facilities management }\end{array}$ & 37 & $0.22 \%$ \\
\hline 8 & Non-metallic mineral products & 13 & $0.46 \%$ & 29 & $\begin{array}{l}\text { Textile clothing, shoes and } \\
\text { hats, leather down and its } \\
\text { products }\end{array}$ & 8 & $0.18 \%$ \\
\hline 9 & Metal products & 15 & $0.42 \%$ & 30 & $\begin{array}{l}\text { Agriculture, forestry, animal } \\
\text { husbandry and fishery } \\
\text { products and services }\end{array}$ & 1 & $0.16 \%$ \\
\hline 10 & Wasted products or materials & 23 & $0.42 \%$ & 31 & Food and tobacco & 6 & $0.15 \%$ \\
\hline 11 & $\begin{array}{l}\text { Electrical machinery and } \\
\text { equipment }\end{array}$ & 19 & $0.37 \%$ & 32 & $\begin{array}{l}\text { Resident services, repairs } \\
\text { and other services }\end{array}$ & 38 & $0.15 \%$ \\
\hline 12 & Buildings & 28 & $0.37 \%$ & 33 & $\begin{array}{l}\text { Public administration, } \\
\text { social security and social } \\
\text { organization }\end{array}$ & 42 & $0.15 \%$ \\
\hline 13 & Leasing and business services & 35 & $0.36 \%$ & 34 & $\begin{array}{l}\text { Culture, sports and } \\
\text { entertainment }\end{array}$ & 41 & $0.13 \%$ \\
\hline 14 & General Equipment & 16 & $0.33 \%$ & 35 & $\begin{array}{l}\text { Information transfer, } \\
\text { software and information } \\
\text { technology services }\end{array}$ & 32 & $0.12 \%$ \\
\hline 15 & Professional equipment & 17 & $0.31 \%$ & 36 & Wholesale and Retail & 29 & $0.11 \%$ \\
\hline 16 & Other manufactured products & 22 & $0.31 \%$ & 37 & Accommodation and dining & 31 & $0.11 \%$ \\
\hline 17 & $\begin{array}{l}\text { Paper printing and cultural and } \\
\text { educational sporting goods }\end{array}$ & 10 & $0.30 \%$ & 38 & Finance & 33 & $0.08 \%$ \\
\hline 18 & Health and social work & 40 & $0.29 \%$ & 39 & Education & 39 & $0.07 \%$ \\
\hline 19 & Transportation equipment & 18 & $0.28 \%$ & 40 & Real estate & 34 & $0.06 \%$ \\
\hline 20 & $\begin{array}{l}\text { Metal products, machinery and } \\
\text { equipment repair services }\end{array}$ & 24 & $0.28 \%$ & & Mean & & $0.40 \%$ \\
\hline 21 & Water production and supply & 27 & $0.28 \%$ & & & & \\
\hline
\end{tabular}

Data source: arranged and measured in accordance with China's 2015 input-output extension table (42 departments). 
chemical products $(0.66 \%)$, the metal smelting and calendering products $(0.62 \%)$, the transportation, warehousing and postal services $(0.60 \%)$, and the real estate products $(0.06 \%)$, with a mean of $0.40 \%$.

The impact of an $10 \%$ price increase in petroleum, coking products and nuclear fuel processed products (11) on the prices of other industries are shown in Table 3.

It is concluded that when the price of the petroleum, coking products and nuclear fuel processed products (No. 11) increases, the prices of other sectors will then go up after being transmitted and influenced owing to the input and output relations between manufacturing sectors, which leads to so-called costdriven price rise. Among all sectors involved in Chinese national economy, the price increase of $10 \%$ in petroleum, coking products and nuclear fuel processed products has different impact on the product prices in other sectors. The one ranked the first is the transportation services, followed in sequence by the warehousing and postal services (1.27\%), the chemical products (1.22\%), the metal smelting and calendering products (1.21\%), the oil and gas extraction products $(1.18 \%)$, the non-metallic minerals and other mining products $(0.88)$, and the real estate $(0.12 \%)$ products. Besides, the mean is shown as $0.56 \%$.

The impact of an $10 \%$ price increase in production and supply of electricity, heat and gas (No. 25-26) on the prices of other industries are shown in Table 4.

As can be seen from Table 4, when the price of the electricity, hot gas, gas production and supply (No. 25-26) increases, the prices of other sectors will then go up after being transmitted and influenced owing to the input and output relations between manufacturing sectors, which leads to so-called cost-driven price rise. There is a big gap in the impact of $10 \%$ increase in prices of the electricity, hot gas, gas production and supply on product prices in different sectors, with a mean of $0.70 \%$. Among them, the water production and supply $(1.87 \%)$ is influenced most deeply, followed in sequence by the metal smelting and calendering products $(1.33 \%)$, the metal mining products $(1.46 \%)$, the metal products $(1.33 \%)$, the non-metallic mineral products $(1.13 \%)$, and the educational products $(0.14 \%)$.

The impact of a $10 \%$ joint increase in the prices of four sectors, including the coal mining products (No. 02), the oil and gas extraction products (No. 03), the petroleum, coking products and nuclear fuel processed products (No. 11), and the production and supply of electricity, heat and gas (No. 25-26) on the prices of other industries are shown in Table 5.

It can be seen from Table 5 that when the prices of the four energy sectors increases at the same time, the prices of other sectors will then go up after being transmitted and influenced owing to the input and output relations between manufacturing sectors, which leads to so-called cost-driven price rise. Of all sectors covered in Chinese national economy, a 10\% joint increase in prices of the four energy sectors at the same time has a big different impact on the price of products in other sectors, with a mean reaching $1.24 \%$, of which the metal 
Table 3. The impact of an increase of $10 \%$ in prices of the petroleum, coking products and nuclear fuel processed products (No. 11) on other industrial products.

\begin{tabular}{|c|c|c|c|c|c|c|c|}
\hline Ranking & Sector & No. & $\begin{array}{l}\text { Variation } \\
\text { Range }\end{array}$ & Ranking & Sector & No. & $\begin{array}{l}\text { Variation } \\
\text { Range }\end{array}$ \\
\hline 1 & $\begin{array}{l}\text { Transportation, warehousing and } \\
\text { postal services }\end{array}$ & 30 & $1.27 \%$ & 22 & Instruments & 21 & $0.48 \%$ \\
\hline 2 & Chemical products & 12 & $1.22 \%$ & 23 & Coal mining products & 2 & $0.47 \%$ \\
\hline 3 & $\begin{array}{l}\text { Metal smelting and calendering } \\
\text { products }\end{array}$ & 14 & $1.21 \%$ & 24 & $\begin{array}{l}\text { Wood processed products and } \\
\text { furniture }\end{array}$ & 9 & $0.47 \%$ \\
\hline 4 & Oil and gas extraction products & 3 & $1.18 \%$ & 25 & $\begin{array}{l}\text { Communication equipment, } \\
\text { computers and other electronic } \\
\text { equipment }\end{array}$ & 20 & $0.47 \%$ \\
\hline 5 & $\begin{array}{l}\text { Non-metallic minerals and other } \\
\text { mining products }\end{array}$ & 5 & $0.88 \%$ & 26 & $\begin{array}{l}\text { Water, environmental and } \\
\text { public facilities management }\end{array}$ & 37 & $0.42 \%$ \\
\hline 6 & Non-metallic mineral products & 13 & $0.88 \%$ & 27 & Textile & 7 & $0.40 \%$ \\
\hline 7 & Metal mining products & 4 & $0.86 \%$ & 28 & Water production and supply & 27 & $0.40 \%$ \\
\hline 8 & $\begin{array}{l}\text { Production and supply of } \\
\text { electricity, heat and gas }\end{array}$ & $\begin{array}{c}25-2 \\
6\end{array}$ & $0.80 \%$ & 29 & $\begin{array}{l}\text { Textile clothing, shoes and hats, } \\
\text { leather down and its products }\end{array}$ & 8 & $0.34 \%$ \\
\hline 9 & Wasted products or materials & 23 & $0.79 \%$ & 30 & $\begin{array}{l}\text { Agriculture, forestry, animal } \\
\text { husbandry and fishery products } \\
\text { and services }\end{array}$ & 1 & $0.31 \%$ \\
\hline 10 & Metal products & 15 & $0.77 \%$ & 31 & $\begin{array}{l}\text { Public administration, social } \\
\text { security and social organization }\end{array}$ & 42 & $0.30 \%$ \\
\hline 11 & Leasing and business services & 35 & $0.74 \%$ & 32 & Food and tobacco & 6 & $0.29 \%$ \\
\hline 12 & $\begin{array}{l}\text { Electrical machinery and } \\
\text { equipment }\end{array}$ & 19 & $0.71 \%$ & 33 & $\begin{array}{l}\text { Resident services, repairs and } \\
\text { other services }\end{array}$ & 38 & $0.29 \%$ \\
\hline 13 & Buildings & 28 & $0.71 \%$ & 34 & $\begin{array}{l}\text { Culture, sports and } \\
\text { entertainment }\end{array}$ & 41 & $0.25 \%$ \\
\hline 14 & General Equipment & 16 & $0.62 \%$ & 35 & $\begin{array}{l}\text { Information transfer, software } \\
\text { and information technology } \\
\text { services }\end{array}$ & 32 & $0.23 \%$ \\
\hline 15 & Professional equipment & 17 & $0.59 \%$ & 36 & Accommodation and dining & 31 & $0.22 \%$ \\
\hline 16 & Other manufactured products & 22 & $0.59 \%$ & 37 & Wholesale and Retail & 29 & $0.21 \%$ \\
\hline 17 & $\begin{array}{l}\text { Paper printing and cultural and } \\
\text { educational sporting goods }\end{array}$ & 10 & $0.56 \%$ & 38 & Finance & 33 & $0.16 \%$ \\
\hline 18 & $\begin{array}{l}\text { Scientific research and } \\
\text { technical services }\end{array}$ & 36 & $0.56 \%$ & 39 & Education & 39 & $0.14 \%$ \\
\hline 19 & Transportation equipment & 18 & $0.54 \%$ & 40 & Real estate & 34 & $0.12 \%$ \\
\hline 20 & Health and social work & 40 & $0.54 \%$ & & & & \\
\hline 21 & $\begin{array}{l}\text { Metal products, machinery and } \\
\text { equipment repair services }\end{array}$ & 24 & $0.52 \%$ & & Mean & & $0.56 \%$ \\
\hline
\end{tabular}

Data source: arranged and measured in accordance with China's 2015 input-output extension table (42 Departments). 
Table 4. The impact of an increase of $10 \%$ in prices of the electricity, hot gas, gas production and supply (No. 25-26) on other industrial products.

\begin{tabular}{|c|c|c|c|c|c|c|c|}
\hline Ranking & Sector & No. & $\begin{array}{l}\text { Variation } \\
\text { Range }\end{array}$ & Ranking & Sector & No. & $\begin{array}{c}\text { Variation } \\
\text { Range }\end{array}$ \\
\hline 1 & Water production and supply & 27 & $1.87 \%$ & 22 & Instruments & 21 & $0.60 \%$ \\
\hline 2 & $\begin{array}{l}\text { Metal smelting and calendering } \\
\text { products }\end{array}$ & 14 & $1.64 \%$ & 23 & $\begin{array}{l}\text { Transportation, warehousing } \\
\text { and postal services }\end{array}$ & 30 & $0.59 \%$ \\
\hline 3 & Metal mining products & 4 & $1.46 \%$ & 24 & Textile & 7 & $0.57 \%$ \\
\hline 4 & Metal products & 15 & $1.33 \%$ & 25 & $\begin{array}{l}\text { Water, environmental and } \\
\text { public facilities management }\end{array}$ & 37 & $0.52 \%$ \\
\hline 5 & Non-metallic mineral products & 13 & $1.13 \%$ & 26 & Health and social work & 40 & $0.52 \%$ \\
\hline 6 & Wasted products or materials & 23 & $1.10 \%$ & 27 & $\begin{array}{l}\text { Textile clothing, shoes and hats, } \\
\text { leather down and its products }\end{array}$ & 8 & $0.43 \%$ \\
\hline 7 & $\begin{array}{l}\text { Non-metallic minerals and } \\
\text { other mining products }\end{array}$ & 5 & $1.07 \%$ & 28 & Leasing and business services & 35 & $0.42 \%$ \\
\hline 8 & Chemical products & 12 & $1.07 \%$ & 29 & $\begin{array}{l}\text { Scientific research and technical } \\
\text { services }\end{array}$ & 36 & $0.41 \%$ \\
\hline 9 & $\begin{array}{l}\text { Petroleum, coking products and } \\
\text { nuclear fuel processed products }\end{array}$ & 11 & $1.00 \%$ & 30 & $\begin{array}{l}\text { Resident services, repairs and } \\
\text { other services }\end{array}$ & 38 & $0.38 \%$ \\
\hline 10 & Coal mining products & 2 & $0.96 \%$ & 31 & Food and tobacco & 6 & $0.30 \%$ \\
\hline 11 & $\begin{array}{l}\text { Electrical machinery and } \\
\text { equipment }\end{array}$ & 19 & $0.93 \%$ & 32 & $\begin{array}{l}\text { Information transfer, software and } \\
\text { information technology services }\end{array}$ & 32 & $0.30 \%$ \\
\hline 12 & General Equipment & 16 & $0.89 \%$ & 33 & $\begin{array}{l}\text { Agriculture, forestry, animal } \\
\text { husbandry and fishery } \\
\text { products and services }\end{array}$ & 1 & $0.27 \%$ \\
\hline 13 & Oil and gas extraction products & 3 & $0.87 \%$ & 34 & Accommodation and dining & 31 & $0.27 \%$ \\
\hline 14 & Buildings & 28 & $0.84 \%$ & 35 & Culture, sports and entertainment & 41 & $0.27 \%$ \\
\hline 15 & $\begin{array}{l}\text { Metal products, machinery and } \\
\text { equipment repair services }\end{array}$ & 24 & $0.81 \%$ & 36 & $\begin{array}{l}\text { Public administration, social } \\
\text { security and social organization }\end{array}$ & 42 & $0.24 \%$ \\
\hline 16 & Professional equipment & 17 & $0.80 \%$ & 37 & Wholesale and Retail & 29 & $0.22 \%$ \\
\hline 17 & $\begin{array}{l}\text { Paper printing and cultural and } \\
\text { educational sporting goods }\end{array}$ & 10 & $0.75 \%$ & 38 & Real estate & 34 & $0.15 \%$ \\
\hline 18 & Transportation equipment & 18 & $0.69 \%$ & 39 & Finance & 33 & $0.14 \%$ \\
\hline 19 & Other manufactured products & 22 & $0.67 \%$ & 40 & Education & 39 & $0.14 \%$ \\
\hline 20 & $\begin{array}{l}\text { Wood processed products } \\
\text { and furniture }\end{array}$ & 9 & $0.63 \%$ & & & & \\
\hline 21 & $\begin{array}{l}\text { Communication equipment, } \\
\text { computers and other electronic } \\
\text { equipment }\end{array}$ & 20 & $0.60 \%$ & & Mean & & $0.70 \%$ \\
\hline
\end{tabular}

Data source: arranged and measured in accordance with China's 2015 input-output extension table (42 departments). 
Table 5. The impact of a simultaneous increase of $10 \%$ in prices of the four sectors on other industrial products.

\begin{tabular}{|c|c|c|c|c|c|c|c|}
\hline Ranking & Sector & No. & $\begin{array}{l}\text { Variation } \\
\text { Range }\end{array}$ & Ranking & Sector & No. & $\begin{array}{l}\text { Variation } \\
\text { Range }\end{array}$ \\
\hline 1 & $\begin{array}{l}\text { Metal smelting and calendering } \\
\text { products }\end{array}$ & 14 & $3.03 \%$ & 20 & Health and social work & 40 & $1.11 \%$ \\
\hline 2 & Chemical products & 12 & $2.41 \%$ & 21 & Instruments & 21 & $1.10 \%$ \\
\hline 3 & Metal mining products & 4 & $2.26 \%$ & 22 & $\begin{array}{l}\text { Communication equipment, } \\
\text { computers and other electronic } \\
\text { equipment }\end{array}$ & 20 & $1.08 \%$ \\
\hline 4 & Non-metallic mineral products & 13 & $2.26 \%$ & 23 & Textile & 7 & $0.98 \%$ \\
\hline 5 & Metal products & 15 & $2.15 \%$ & 24 & $\begin{array}{l}\text { Scientific research and technical } \\
\text { services }\end{array}$ & 36 & $0.96 \%$ \\
\hline 6 & Water production and supply & 27 & $2.15 \%$ & 25 & $\begin{array}{l}\text { Water, environmental and public } \\
\text { facilities management }\end{array}$ & 37 & $0.93 \%$ \\
\hline 7 & $\begin{array}{l}\text { Non-metallic minerals and } \\
\text { other mining products }\end{array}$ & 5 & $1.94 \%$ & 26 & $\begin{array}{l}\text { Textile clothing, shoes and hats, } \\
\text { leather down and its products }\end{array}$ & 8 & $0.78 \%$ \\
\hline 8 & Wasted products or materials & 23 & $1.93 \%$ & 27 & $\begin{array}{l}\text { Resident services, repairs and } \\
\text { other services }\end{array}$ & 38 & $0.66 \%$ \\
\hline 9 & $\begin{array}{l}\text { Transportation, warehousing } \\
\text { and postal services }\end{array}$ & 30 & $1.74 \%$ & 28 & Food and tobacco & 6 & $0.58 \%$ \\
\hline 10 & $\begin{array}{l}\text { Electrical machinery and } \\
\text { equipment }\end{array}$ & 19 & $1.71 \%$ & 29 & $\begin{array}{l}\text { Agriculture, forestry, animal } \\
\text { husbandry and fishery products } \\
\text { and services }\end{array}$ & 1 & $0.57 \%$ \\
\hline 11 & Buildings & 28 & $1.61 \%$ & 30 & $\begin{array}{l}\text { Information transfer, software and } \\
\text { information technology services }\end{array}$ & 32 & $0.53 \%$ \\
\hline 12 & General Equipment & 16 & $1.55 \%$ & 31 & $\begin{array}{l}\text { Public administration, social security } \\
\text { and social organization }\end{array}$ & 42 & $0.52 \%$ \\
\hline 13 & Professional equipment & 17 & $1.42 \%$ & 32 & Culture, sports and entertainment & 41 & $0.51 \%$ \\
\hline 14 & Other manufactured products & 22 & $1.42 \%$ & 33 & Accommodation and dining & 31 & $0.47 \%$ \\
\hline 15 & $\begin{array}{l}\text { Paper printing and cultural and } \\
\text { educational sporting goods }\end{array}$ & 10 & $1.38 \%$ & 34 & Wholesale and Retail & 29 & $0.41 \%$ \\
\hline 16 & $\begin{array}{l}\text { Metal products, machinery and } \\
\text { equipment repair services }\end{array}$ & 24 & $1.35 \%$ & 35 & Finance & 33 & $0.29 \%$ \\
\hline 17 & Transportation equipment & 18 & $1.26 \%$ & 36 & Education & 39 & $0.27 \%$ \\
\hline 18 & Leasing and business services & 35 & $1.13 \%$ & 37 & Real estate & 34 & $0.26 \%$ \\
\hline 19 & $\begin{array}{l}\text { Wood processed products and } \\
\text { furniture }\end{array}$ & 9 & $1.12 \%$ & & Mean & & $1.24 \%$ \\
\hline
\end{tabular}

Data source: arranged and measured in accordance with China's 2015 input-output extension table (42 Departments).

smelting and calendering products (3.03\%) are ranked No. 1, followed by the chemical products $(2.41 \%)$, the metal mining products $(2.26 \%)$, the non-metallic mineral products $(2.26 \%)$, the non-metallic mineral products $(2.15 \%)$, and the real estate products $(0.26 \%)$. 


\section{Results Analysis}

The empirical results demonstrate that the rise in energy prices may drive up prices of other industrial products. The reason lies in the fact that an increase in energy products will be transmitted to products in other sectors during the manufacturing process following the input-and-output rule, which surely leads to a cost-driven price rise. Especially, when several kinds are bounded altogether in price rise, a pulling effect on other industry prices will be generated prominently.

More precisely, a $10 \%$ increase in the prices of coal products (No. 02) led to the same trend in prices of other sectors at an average range of $0.36 \%$. Among them, the impact on the production and supply of electricity, heat and gas was the largest $(2.06 \%)$, with a change of over 1.14 percentage points more than that of the second-ranked petroleum, coking products and nuclear fuel processed products $(0.92 \%)$. A $10 \%$ increase in the prices of oil and gas extraction products (No. 03) led to the same trend in prices of other sectors at an average range of $0.40 \%$. Among them, the impact on the petroleum, coking products and nuclear fuel processed products was the largest (4.46\%), with a change of about $3.62 \%$ more than that of the second-ranked production and supply of electricity, heat and gas $(0.84 \%)$. A $10 \%$ increase in the prices of Petroleum, coking products and nuclear fuel processed products (No. 11) led to the same trend in prices of other sectors at an average range of $0.56 \%$. Among them, the impact on the transportation, warehousing and postal services was the largest (1.27\%), with a change of about $0.05 \%$ more than that of the second-ranked chemistry products (1.22\%). A $10 \%$ increase in the prices of Electricity, hot gas, gas production and supply (No. 25 - 26) led to the same trend in prices of other sectors at an average range of $0.70 \%$. Among them, the impact on the water production and supply was the largest $(1.87 \%)$, with a change of about $0.54 \%$ more than that of the secondranked metal smelting and calendering products (1.33\%).

In fact, the impact of price increase in the four energy sectors on the prices of other industries is not simply a summation, but may result in a price decline, which will not occur when only a single sector is involved. The reason is that the input-output price model does not take into account the effects of demand and conduction factors, but assumes that the input coefficients in the production function are fixed, and that no substitution relationship exists between products. Therefore, when the prices of the four energy sectors change simultaneously, the price increase does not exactly equal the sum of the change in the four energy sectors, which is adjusted internally by the input-output price model. Compared with other energy products, the increase in coal prices has the least impact on the prices of other industrial products, indicating that China's dependence on coal is gradually decreasing.

So far, China has witnessed a dramatic demand for a variety of energy with the rapid growth of economy. The coal and petroleum energy industries, however, have suffered from overcapacity in a certain degree since China's economy 
stepped into a new normal stage. What's worse, improper energy pricing has become a bottle restricting industrial development. The price of some energy resource products cannot fully reflect its value, which not only causes waste of resources, but prevent economic regulation. It is the transitional stage where China's energy price is no longer totally decided by the government, but actually by the market gradually. In a word, changes in energy prices will influence both the energy industry and other industries by altering energy consumption structure, energy production methods and consumption patterns, thereby empowering energy markets in China and even around the world.

In this case, individual pricing measures are suggested to tailor each energy product in the way of maximizing its own value, in hopes of bringing down energy consumption and thereby achieving equilibrium prices.

\section{Fund}

This paper is a phased result of the 2015 National Social Science Fund Project: A study on the economic effect of carbon tax under the constraint of carbon emission reduction (15bgl144).

\section{Conflicts of Interest}

The authors declare no conflicts of interest regarding the publication of this paper.

\section{References}

[1] Lin, B. and Wang, F. (2009) The Impact of Rising Energy Prices on China's General Price Level. Economics Research, 44, 66-79.

[2] Hotelling, H. (1931) The Economics of Exhaustable Resources. The Journal of Political Economy, 39, 137-175. https://doi.org/10.1086/254195

[3] Arrow, K.J. and Chang, S. (1982) Optimal Pricing, Use, and Exploration of Uncertain Resource Stocks. Journal of Environmental Economics and Management, 9, 1-10. https://doi.org/10.1016/0095-0696(82)90002-X

[4] Hamilton, J.D. (1983) Oil and the Macro-Economy Since World War II. Journal of Political Economy, 91, 228-248. https://doi.org/10.1086/261140

[5] Burbidge, J. and Harrison, A. (1984) Testing for the Effects of Oil-Price Rises Using Vector Auto-Regressions. International Economic Review, 25, 459-484. https://doi.org/10.2307/2526209

[6] Adelman, M.A. (1993) The Economics of Petroleum Supply. MIT Press, Cambridge, MA.

[7] Lee, K. and Ni, S. (2002) On the Dynamic Effects of Oil Price Shocks: A Study Using Industry Level Data. Journal of Monetary Economics, 49, 823-852.

https://doi.org/10.1016/S0304-3932(02)00114-9

[8] Jiménez-Rodríguez, R. and Sánchez, M. (2005) Oil Price Shocks and Real GDP Growth: Empirical Evidence for Some OECD Countries. Applied Economics, 37, 201-228. https://doi.org/10.1080/0003684042000281561

[9] Ren, Z., Pan, W. and Liu, Q. (2007) The Impact of Crude Oil Price Fluctuation on China's Price-Based on Input-Output Price Model. Statistics Research, 11, 22-28. 
[10] Lin, B. and Mu, D. (2008) The Impact of Energy Prices on Macroeconomics: An Analysis Based on Computable General Equilibrium (CGE). Economics Research, 43, 88-101.

[11] Ren, Z. (2012) Potential and Actual Impact of Energy Price Volatility on China's Price Level. Economics Research, 47, 59-69.

[12] Wang, W., Dong, D., Zhao, L. and Xu, C. (2012) Analysis of the Impact of Coal Price Change on National Economy Based on Input-Output Model. Coal Science and Technology, 40, 125-128.

[13] Yang, J. and Song, X. (2012) Research on the Impact of Coal Price on China's Related Industries-Based on Input-Output Analysis. Economic Issues, 11, 33-35.

[14] Zhang, X., Wang, H. and Feng, L. (2013) Impact Analysis of Fossil Energy Price Change-Based on Input-Output Price Model. Technology Economy, 32, 63-69.

[15] Zhang, H., Zhan, G. and Jin, R. (2013) Empirical Analysis of China's Energy Price and Related Industry Price Impact Mechanism-Based on Input-Output Price Model. Journal of Beijing Institute of Technology, 15, 32-38.

[16] Xu, X. and Gao, H. (2014) Empirical Study on the Influence of China's Coal Price on the Overall GDP Price Level and Related Industry Price. China Population, Resources and Environment, 24, 155-158.

[17] He, Y. and Sun, W. (2017) The Impact of International Natural Gas Price Fluctuation on Residents' Living and Industrial Structure: A Policy Simulation Based on Non-Competitive CGE Model. Journal of Yunnan University of Finance and Economics, 33, 72-81.

[18] Dong, C. and Wang, S. (2012) Input and Output. China's Statistics Press, Beijing, 179-191.

[19] Liu, Q. and Chen, Z. (2011) Input-Output Analysis. China Renmin University Press, Beijing, 185-192.

[20] Xia, M. and Zhang, H. (2012) Input-Output Analysis Theory, Methods and Data. China Renmin University Press, Beijing, 211-218.

[21] Chen, X. and Yang, C. (2011) Input-Output Technology. Science Press, Beijing, 348-363. 